\title{
Greetings from the editor 2019
}

First of all, let me wish you a healthy, happy and prosperous New Year-may your personal and professional wishes come true. Second, let me thank you for your continued support of the Annals of the Rheumatic Diseases (ARD)—as readers, as authors, as reviewers or as members of our team. Finally, please allow me to look back at the past year from the perspective of the Editor.

As I had promised in my previous greetings note, ${ }^{1}$ we started three new sections in 2018: 'Views on News', 'Heroes and Pillars of Rheumatology' and 'Thinking the Unthinkable'. Three 'Views on News' were published last year and conveyed what the authors thought were publications in other journals with important implications for our field. $^{2-4} \mathrm{~A}$ first publication on a hero in the 'Heroes and Pillars of Rheumatology' part has also appeared, ${ }^{5}$ a section intended to tell the younger rheumatologists about people (or publications) that paved the roads to modern rheumatology-more will follow. Finally, $A R D$ also made an initial blink into the 'unthinkable' future, ${ }^{6}$ which already elicited an interesting online discussion. ${ }^{78}$

$A R D$ has also promised to provide readers with actual data for all data points in all figures in articles on clinical trials. ${ }^{1}$ This is in the process of implementation, as can be seen already in some trial papers published in recent months; the data are shown either directly in the publication (such as in ref 9) or in supplementary materials (such as in ref 10). We sincerely hope that in the future-thinking the thinkable-no publication on clinical trials in any journal will show figures without revealing the data for all data points.

But where are we heading to in 2019? Well, first we have noticed that supplementary materials are often difficult to access in our journal and others. We do not want frustrated readers and, therefore, from 2019 on we will provide the supplementary materials downloadable with the pdf files of the respective articles. This will enable our readers to have access to important information without having to search in the web-sometimes in vain. Second, we realised recently that our instructions to authors may benefit from incorporating some additional aspects of transparency in the context of the submission, decision and publication processes. These have to be aligned with other $B M J$ journals, and soon our instructions to authors will provide unambiguous information in this respect, developed in collaboration with the chair of our advisory board which serves as an ethical guidance committee for the journal. Third, we will expand our editorial board by including patients; this will not only allow us to follow BMJ's Patient and Public Partnership strategy, but patients are part of European League Against Rheumatism's (EULAR) constituency and we appreciate their input in all areas of the organisation. Patients will serve as reviewers of research papers and, thus, their participation in shaping the content of the journal will go beyond their contributions to recommendations. We will also continue developing lay versions of research that is published in $A R D$ and deems to be especially important to patients.

Needless to say that $A R D$ also welcome your suggestions on contents and concepts so that they can contribute to the development of the journal. Please send your thoughts to the editorial office at ard@ bmj.com.

There will also be some small but visible structural changes in ARD. From now on, the page headings will refer to the topics covered by the respective articles rather than focusing on whether a paper deals with a clinical or basic research question. This will enable us to serve you even better in our continued efforts to focus on the newest developments in clinical, epidemiological and translational research, attempting to meet the quality standards that you expect and which this journal stands for.

When speaking about serving you, the readers of this journal, it is a pleasure to mention that $A R D$ has done so for 80 years. Believe it or not: $A R D$ celebrates its 80th anniversary this year. The oldest journal in rheumatology started its activity back in 1939! The first volume's papers dealt with 'acute rheumatism', rheumatoid arthritis, juvenile arthritis and gout ${ }^{11-13}$; the systemic anti-inflammatory effect of gold therapy was addressed ${ }^{14}$ (reminding us of some of the groundbreaking work of the first "hero, ${ }^{5}$ mentioned above which formed a foundation for that article); and several papers dealt with the possible causes of rheumatic diseases. ${ }^{15}$ 16 But also societal aspects received attention, ${ }^{17}$ and Philip Hench ${ }^{18}$ wrote an article on research in rheumatic diseases, long before he received the Nobel Prize for his seminal work on glucocorticoids. Thus, already 80 years ago the journal was dedicated to advance the field, a dedication that we have maintained until today and are determined to further expand over the next years.

But 2019 also marks another anniversary: 20 years ago EULAR decided to acquire a rheumatology journal and you hold the result of these deliberations in your hands-the EULAR Journal, a journal that is co-owned and comanaged by both $B M J$ and EULAR in the best collegial way, devoted to serving the field of rheumatology. The journey that ARD has taken from being a relatively small journal to one that is used by almost 15000 subscribers and tens of thousands other readers is exemplary for what can be achieved even in the days of digital publishing. $A R D$ serves both, those who wish to hold a print issue in their hands as well as those who wish to read papers online. And the 'online first' publications that this journal offers have already the same typeset and quality as the final print version will have-for your reading pleasure.

However, there is yet another anniversary that I would like to make you aware of: in 2009 EULAR founded the 'Emerging EULAR NETwork' (EMEUNET), to provide high-quality, young-generation rheumatologists with an opportunity to contribute to all EULAR activities. All EULAR activities? Of course: all activities, including the EULAR Journal. Members of EMEUNET are on the editorial board of $A R D$ as well as of our sister journal $R M D$ Open, and both journals have established a peer review mentoring programme to train EMEUNET members as reviewers. Congratulations to EMEUNET on the occasion of its 10th anniversary and many thanks to the many reviewers who have served and serve as mentors for EMEUNET; most, if not all, of their mentees have developed excellent skills and need to be applauded. EMEUNET is also supporting $A R D$ with respect to social network activities, which is gratefully acknowledged.

But now back to the future, back to this very first issue in 2019. As mentioned above, $A R D$ will continue along the paths set forth during this decade and also continue providing you with the newest recommendations and criteria, primarily based on EULAR activities or combined efforts of the American College of Rheumatology and EULAR. And a first such recommendation paper for 2019 is brought to you in this very issue of ARD. ${ }^{19}$ 
Enjoy reading it and all the other papers that meet your interests in this and the subsequent issues.

Again a happy 2019.

\section{Josef S Smolen}

(c) Author(s) (or their employer(s)) 2019. No commercial re-use. See rights and permissions. Published by BMJ.

\section{D) Check for updates}

To cite Smolen JS. Ann Rheum Dis 2019;78:1-2.

Ann Rheum Dis 2019;78:1-2.

doi:10.1136/annrheumdis-2018-214822

\section{REFERENCES}

1 Smolen JS. Greetings from the editor. Ann Rheum Dis 2018;77:789.

2 Pisetsky DS. How the gut inflames the joints. Ann Rheum Dis 2018;77:634-5.

3 Pisetsky DS. Role of Epstein-Barr virus infection in SLE: gene-environment interactions at the molecular level. Ann Rheum Dis 2018;77:1249-50.
4 Radstake T. Extraintestinal translocation of microbes and tissue specificity in rheumatic musculoskeletal disease (RMD): its more than a gut feeling. Ann Rheum Dis 2018;77:1702-4.

5 Dougados M, Dougados Jacques M. M. Jacques FORESTIER, a visionary of the clinical epidemiology in rheumatology. Ann Rheum Dis 2018;77:1097-8.

6 Burmester GR. Rheumatology 4.0: big data, wearables and diagnosis by computer. Ann Rheum Dis 2018;77:963-5.

7 Ravindran V, Kataria S. Digital health in rheumatology. Ann Rheum Dis 2018:annrheumdis-2018-214146.

8 Burmester GR. Response to: 'Digital health: a new dimension in rheumatology patient care' by Kataria and Ravindran. Ann Rheum Dis 2018:annrheumdis-2018-214154.

9 Morand EF, Trasieva T, Berglind A, et al. Lupus Low Disease Activity State (LLDAS) attainment discriminates responders in a systemic lupus erythematosus trial: post-hoc analysis of the Phase Ilb MUSE trial of anifrolumab. Ann Rheum Dis 2018;77:706-13.

10 Hissink Muller P, Brinkman DMC, SchonenbergMeinema D. Treat to target (drug-free) inactive disease in DMARD-naive juvenile idiopathic arthritis: 24-month clinical outcomes of a three-armed randomised trial. Ann Rheum Dis 2019;78:51-9.
11 Collins DH. Observations on the pathology of acute rheumatism and rheumatoid arthritis. Ann Rheum Dis 1939; 1:38-45.

12 Bach F, Hill NG, Preston TW, et al. Juvenile rheumatism in London. Ann Rheum Dis 1939:1:210-41.

13 Burt JB, Gordon RG. Gout an Unsolved Problem. Ann Rheum Dis 1939;1:304-18.

14 Goldie W. The effect of chrysotherapy on the sedimentation rate in rheumatoid arthritis. Ann Rheum Dis 1939;1:319-32.

15 Levinthal W. The AEtiological Problem of Rheumatism. Ann Rheum Dis 1939;1:67-85.

16 Dyson CB. Some incidental observations on the possibility of a virus as part causal factor in rheumatism. Ann Rheum Dis 1939;1:15-17.

17 Duthie JJ. The sociological aspects of the treatment of arthritis: notes on a visit to the United States. Ann Rheum Dis 1939;1:201-9.

18 Hench PS. Recent researches on arthritis and rheumatism in the United States. Ann Rheum Dis 1939;1:109-33.

19 Kloppenburg M, Kroon FP, Blanco FJ, et al. 2018 update of the EULAR recommendations for the management of hand osteoarthritis. Ann Rheum Dis 2019;78:16-24. 